\title{
Application of Caco-2 Cell Line in Herb-Drug Interaction Studies: Current Approaches and Challenges
}

\author{
C. Awortwe ${ }^{1}$, P.S. Fasinu², B. Rosenkranz ${ }^{1}$ \\ ${ }^{1}$ Division of Clinical Pharmacology, Faculty of Medicine and Health Sciences, University of Stellenbosch, Tygerberg, Cape \\ Town, South Africa. ${ }^{2}$ National Center for Natural Products Research, School of Pharmacy, University of Mississippi, Oxford, \\ USA.
}

Received, August 23, 2013; Revised, December 27, 2013; Accepted, January 4, 2014; Published, January 6, 2014.

\begin{abstract}
The Caco-2 model is employed in pre-clinical investigations to predict the likely gastrointestinal permeability of drugs because it expresses cytochrome P450 enzymes, transporters, microvilli and enterocytes of identical characteristics to the human small intestine. The FDA recommends this model as integral component of the Biopharmaceutics Classification System (BCS). Most dedicated laboratories use the Caco-2 cell line to screen new chemical entities through prediction of its solubility, bioavailability and the possibility of drug-drug or herbdrug interactions in the gut lumen. However, challenges in the inherent characteristics of Caco-2 cell and interlaboratory protocol variations have resulted to generation of irreproducible data. These limitations affect the extrapolation of data from pre-clinical research to clinical studies involving drug-drug and herb-drug interactions. This review addresses some of these caveats and enumerates the plausible current and future approaches to reduce the anomalies associated with Caco- 2 cell line investigations focusing on its application in herb-drug interactions.
\end{abstract}

This article is open to POST-PUBLICATION REVIEW. Registered readers (see "For Readers") may comment by clicking on ABSTRACT on the issue's contents page.

\section{INTRODUCTION}

Oral administration of drugs and xenobiotics is the most convenient route of drug administration $(1,2)$. Oral drug absorption is complex; characterized by multiple challenges including the inherent characteristics of the formulation, the physiological conditions and the physicochemical properties of the drugs (3) . Additionally, intestinal enterocytes present a well-structured defensive system to modulate entry of drugs and xenobiotics from gut lumen into the systemic circulation. Metabolism and transport of drugs across intestinal membrane are therefore multifaceted and dynamic process involving both passive and active transport mechanisms (Figure 1). Hence, transmembrane absorption is generally recognized as a basic condition to ensure efficient systemic availability of drugs via the gastro-intestinal tract.

Research scientists and pharmaceutical companies employ cell-based assays such as Caco-2 cells and Mardin-Darby canine kidney (MDCK); artificial lipid-based systems including parallel artificial membrane permeability assay (PAMPA) as preclinical high throughput screening models for evaluation of intestinal permeability of drugs and herbal supplements $(4,5,6,7)$. The Caco- 2 cell line derived from human colon adenocarcinoma is considered the most common in vitro model used for investigation and prediction of intestinal drug absorption (8). It undergoes spontaneous enterocytic differentiation in appropriate culture to become polarized cells expressing apical and basolateral surfaces with well-established tight junctions. The polarized cells depict several functions of normal enterocytes including expression of brush border enzymes, some cytochrome (CYP) isoenzymes and phase II enzymes (9). The model is also employed in identification of substrates and/or inhibitors of drug transporters (10) . Caco-2 cell line is used for screening of conventional drugs and new chemical entities for potential drug-drug interactions. However, its application in most dedicated laboratories and research institutions for screening herbal medications for likely herb-drug interactions is gaining popularity.

Corresponding Author: Charles Awortwe; Division of Clinical Pharmacology, Faculty of Medicine and Health Sciences, University of Stellenbosch, Tygerberg, Cape Town, South Africa; E-mail address: charzos@yahoo.com 
In recent years, consumption of herbal remedies either in combination with conventional drugs or alone has become a common practice in patients suffering from chronic diseases such as HIV/AIDS and cancer $(11,12)$. Unfortunately, most physicians are unaware of this habit which may likely cause therapeutic failure and/or toxicity due to high propensity of such individuals experiencing herbdrug interactions (13).

Currently, studies on herb-drug interactions have increased due to the awareness of the possible threats it may pose to both patients and healthcare providers in an attempt to achieve optimum therapeutic objectives. The pharmacokinetic herb-drug interactions are mostly attributed to inhibition or induction of drug metabolism enzymes and transporters or renal drug clearance. The use of Caco-2 cell line to screen herbal remedies for possible herb-drug interactions may reduce the probability of associated therapeutic failure, adverse effects, and cost of treatment and withdrawal of herbal products from the market.

Although most researchers and pharmaceutical industries prefer Caco-2 as an in vitro model for investigation of intestinal drug absorption, mixed reports have been published regarding its in vivo correlation with humans (14). The deficiencies associated with Caco-2 cell line as a preclinical model for prediction of intestinal permeability may yield inaccurate results in herb-drug interactions investigations. This review aims to appraise the utilization of Caco-2 cell lines in preclinical studies, address some of the associated limitations and the emerging approaches to resolve these problems. The emerging approaches addressed in this review may be beneficial to minimize current and future challenges likely to undermine the application of Caco-2 cell line for herb-drug interaction studies.

\section{Search strategy and selection criteria}

The review was conducted systematically by searching the databases of EBSCOHOST, MEDLINE, PUBMED, EMBASE, GOOGLE SCHOLAR, and COCHRAINE libraries for original researches that include the following combination search terms: "Caco-2 cell line", "drug permeability and/or absorption", "herb-drug interactions", "pitfalls and current approaches". The literature searches were limited to publications that are available online in English language. There was no limitation to dates of publication nevertheless in cases of recurrence of search results, the most recent was preferred.

\section{Mechanisms of intestinal drug absorption}

Absorption of herbal supplements and drugs mainly occurs at the duodenum and jejunum segments of small intestine due to high concentrations of villi and microvilli which provide a large surface area $(15,16$, 17, 18). The epithelial cells in these regions are heterogeneous with enterocytes responsible for the absorption of most pharmacological agents. The enterocytes are polarized with distinct apical and basolateral membranes separated by tight junctions. This architectural composition of polarized enterocytes restricts the passage of drugs and xenobiotics through either passive diffusion or carrier-mediated processes (19). The large surface area serves as a conduit for efficient permeation of drugs through various mechanisms including passive and active pathways. Passive diffusion encompasses two routes: the paracellular pathway which facilitates permeation of hydrophilic drugs of low molecular weight and peptides via aquaporins at the tight junctions between the enterocytes; and the transcellular pathway responsible for movement of lipophilic drugs across lipid cell membrane of the enterocytes. Presence of tight junctions in the intercellular space limits the free flow of compounds traversing the intestinal epithelium via the paracellular process (20). The carrier-mediated transport processes involve both facilitated and active mechanisms engineered by transport proteins responsible for uptake or efflux of drugs in the intestine as shown in figure $1(21,22,23)$.

Uptake and efflux transporters are localized at both the apical side and basolateral membranes of the intestinal enterocytes. Efflux transporters commonly expressed in the intestine membranes include Pglycoprotein (P-gp), multidrug resistance proteins (MRP 1-6), and breast cancer resistance protein (BCRP). These are members of the ATP-binding cassette (ABC) transport proteins which utilise ATP as energy source to transport substrates against a concentration gradient $(24,25,26)$ from the cytoplasm of intestinal cells back to the intestinal lumen or to the blood.

Primary active efflux transporters notably P-gp, MRP2, and BCRP are well expressed on brushborder apical membrane of the enterocytes and reported to form major hindrance to intestinal absorption of drugs $(27,28)$. $(29,30)$. 

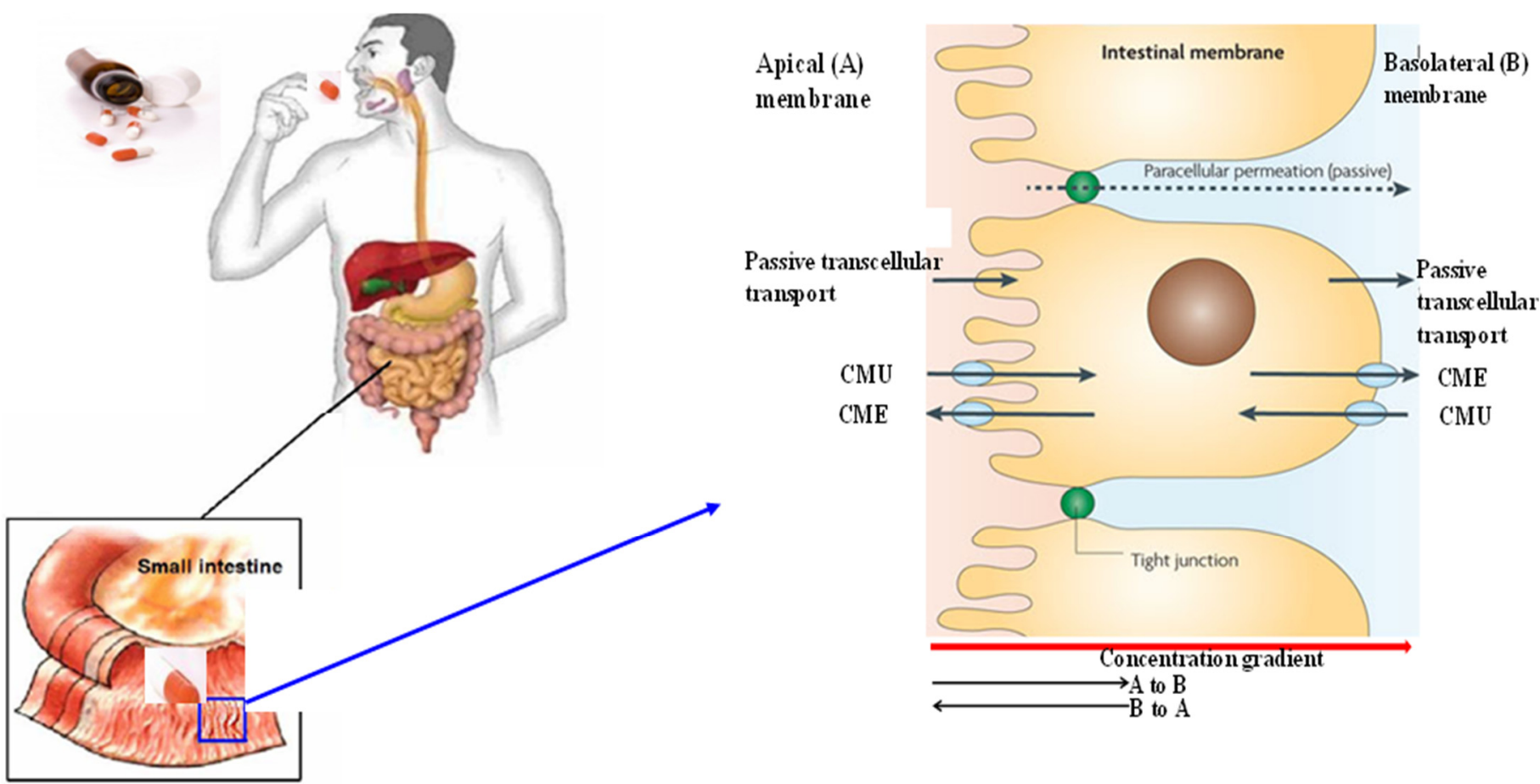

Figure 1. Pathways of drug absorption through intestinal enterocytes modified from Sugano et al. (27): carrier-mediated uptake (CMU), carrier-mediated efflux (CME), absorptive direction (A to $\mathrm{B}$ ) and excretive direction (B to $\mathrm{A})$.

These have the tendency to reduce oral bioavailability of specific drugs by expulsion from the enterocytes into intestinal lumen P-gp is a wellrecognized efflux transporter which influences absorption and excretion of several drugs due to its wider range of substrate specificity (31). BCRP is capable to extrude glucuronides and sulfate conjugates formed in the enterocytes into the lumen, although its main function relates to excretion of drugs and xenobiotics into breast milk and a defensive role at the placental barrier (32). MRP2 plays an important role in detoxification of drug and xenobiotics which have undergone phase II metabolism to facilitate excretion $(33,34)$. Unlike efflux transporters, apical membrane uptake transporters increase absorption of drugs from the lumen into the enterocytes $(35,36)$. Finally, receptormediated endocytosis could also play a role in drug absorption.

Uptake transporters e.g., peptide transporter (PEPT), organic anion transporter (OAT), organic anion transporting polypeptide (OATP), organic cation transporter (OCT) are members of solute carrier (SLC and SLCO) superfamilies and function independent of ATP but rather transport drugs according to their concentration gradient (Figure 2).

In the Caco-2 cell permeability assessment of drugs and herbal supplements, adequate expression of transport proteins can be utilized to predict the possible degree of bioavailability upon coadministration (37). Most transporters aforementioned can be expressed in Caco- 2 cell under appropriate culture media. Table 1 below describes the uptake and efflux transporters that are likely to be expressed in the Caco-2 cell line. Despite the possibility of expression of most transporters in the Caco-2 cell, some transporters like hPEPT1 are poorly developed except under modified conditions such as tease out or molecularly engineered manipulations. Few of these limitations will be subsequently discussed in detail.

\section{Caco-2 cell line}

The Caco-2 cell line is the most common and extensively characterized cell-based model for the assessment of absorption of drugs via the intestinal membrane enterocytes $(38,39,40)$. 


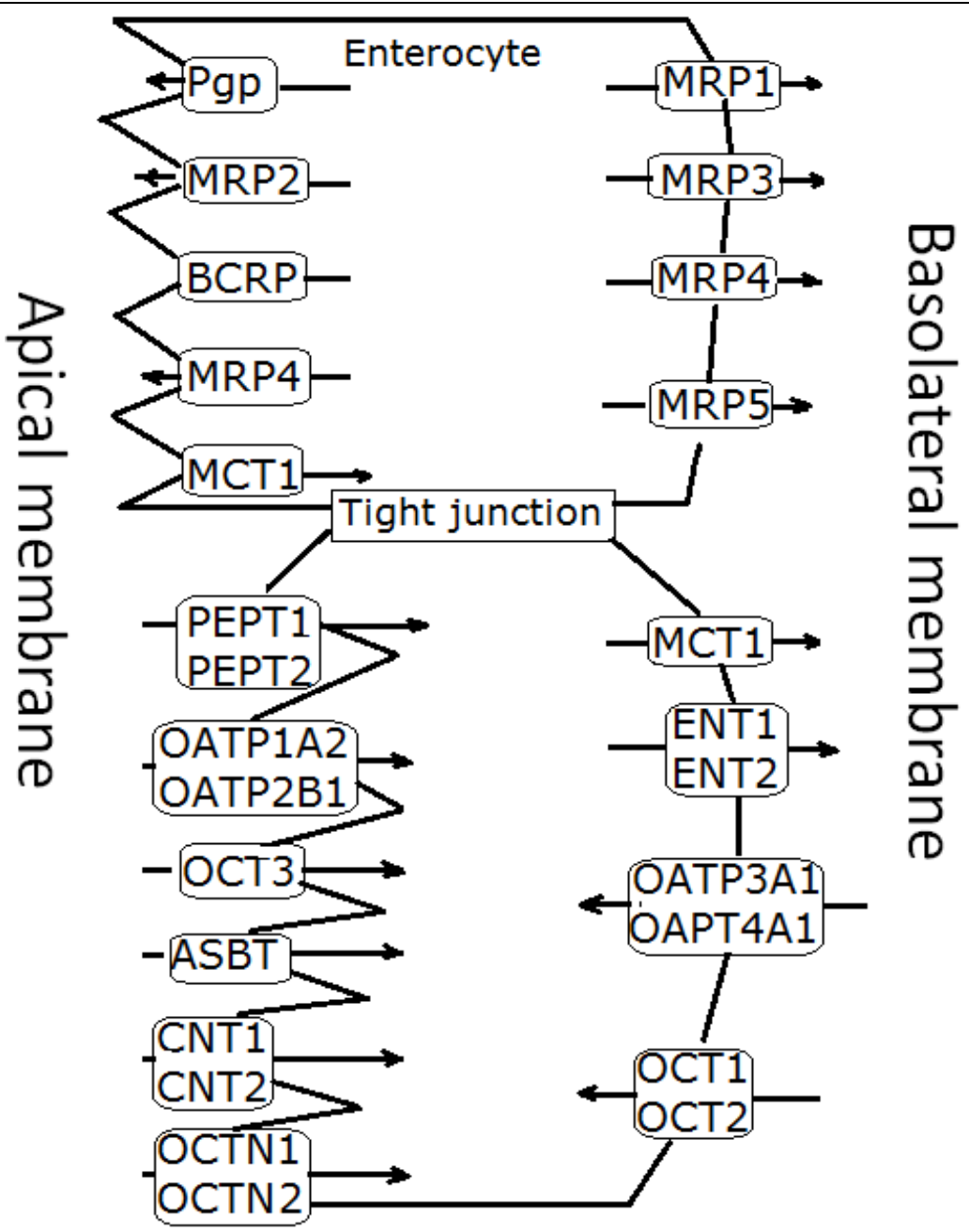

Figure 2. Localization of ABC and SLC transporters in human small intestine adapted from Smetanová et al. (38)

It is derived from heterogenous human epithelial colorectal adenocarcinoma cells, developed through research by Jorgen Fogh (1975) at Sloan-Kettering Institute for Cancer Research (41). The Caco-2 cells have the intrinsic ability to initiate spontaneous differentiation on reaching confluence in the presence of normal culture conditions. At confluence, there is progressive development of brush border. The surface occupied by each cell gradually reduces from 5 to 20 days post-confluence and intimate intercellular junctions are developed. During the same period, the length and density of microvilli increase. The Caco-2 cells form well developed tight junctions after 21 days of culturing. At day - 30 post-confluence, the cell surface reaches minimum with typical enterocytes-like morphology. Most cells develop complete brush borders with tall and regular microvilli when the full structural polarization is achieved after 30 days (42). The complete polarized Caco-2 cells resemble human small intestinal mucosa cells expressing brush borders, tight junctions and, efflux and uptake transporters at both apical and basolateral compartments.

The Caco- 2 cell line fairly represent intestinal biochemical barrier due to expression of membrane efflux proteins (P-gp, MRP 1-3), CYP450 isoenzymes and phase II conjugating enzymes such as sulfotransferase, UDP-glucuronyltransferase, glutathione S-transferase $(43,44)$. Table 2 summarizes the characteristics of a parental Caco-2 cell line. Permeability of substrate via the Caco-2 cell monolayer has proven to correlate closely with oral absorption in humans compared with other parental cell-based models. Currently, Caco-2 monolayers are applied for screening the potential effects of herbs and new chemical entities (NCE) on absorption of drugs. 
Table 2. Characteristics of Caco- 2 cell line

\author{
Parameter \\ Origin \\ Growth in culture \\ Differentiation \\ Morphology \\ Electrical resistance \\ Digestive enzymes
}

Active transport

Membrane ionic transport

\author{
Description \\ Human colorectal adenocarcinoma \\ Monolayer epithelial cells \\ 14-21 days after confluence in standard culture medium \\ Polarised cells, with tight junctions, apical brush border \\ High transepithelial electrical resistance (TEER) \\ Typical membranous peptidases and disaccharidases of the small \\ intestine \\ Amino acids, sugars, vitamins, hormones \\ $\mathrm{Na}^{+} / \mathrm{K}^{+}$ATPase, $\mathrm{H}^{+} / \mathrm{K}^{+}$ATPase, $\mathrm{Na}^{+} / \mathrm{H}^{+}$exchange, $\mathrm{Na}^{+} / \mathrm{K}^{+} / \mathrm{Cl}^{-}$. co- \\ transport, apical $\mathrm{Cl}^{-}$. channels
}

\section{Comparison of Caco-2 with other cell-based models for intestinal permeability studies}

The Madin-Darby canine kidney (MDCK) is considered as an alternative to Caco- 2 cell for permeability studies. The MDCK cell line is derived from the normal dog kidney. When cultured in an appropriate media, MDCK differentiate into columnar epithelial cells with clear tight junctions similar to Caco-2 formed within on a semipermeable membrane. The differentiated MDCK cell maintains characteristics of kidney epithelial cells such as asymmetric distribution of enzymes and vectorial transport of sodium and water from the apical to the basolateral membrane (45). The MDCK has a shorter cultivation period ( 3 - 5 days) compared to 21 days of Caco -2 cell line. Furthermore, the transepithelial electrical resistance (TEER) of MDCK cells is lower and closer to that of small intestine compared to Caco- 2 cell. This often results in a higher permeability coefficient of hydrophilic compounds in MDCK cells than Caco- 2 cell. The shorter culture duration is advantageous since it reduces cost, time, and enhances high throughput. The MDCK cell line appears to be more robust and need less rigorous nutritional schedule over a short incubation period relative to Caco- 2 cell. However, these cells are derived from dog kidney and therefore there is a high propensity of differences in the expression levels of some transporters and metabolic activity as compared to Caco-2 cell (46).

LLC-PK1 cells derived from pig kidney epithelial have also been employed as an alternative model to Caco-2 cells for assessing permeability of test compounds. Studies have reported the use of LLC-PK1 for characterization of passive absorption of test compounds $(47,48,49)$.

The human adenocarcinoma HT29-MTX model is used to investigate the role of intestinal mucus on drug absorption across the intestinal barrier. The HT29-MTX is conditioned to acquire the morphological and mucin producing features of goblet cells by culturing parental HT29 in a medium containing $10^{-6} \mathrm{M}$ methotrexate for six months $(50,51)$. Unlike Caco-2, HT29-MTX develops sparse microvilli on the apical side and reaches confluence 3 days later than the former. However, expression of goblet cells in HT29-MTX increases absorption of lipophilic compounds compared to Caco-2 monolayer.

TC-7, a subclone of Caco-2 cells, is also used for permeability screening of tests compounds. The TC7 clone displays morphological features of brushborder membrane, microvilli and tight junctions similar to Caco-2 monolayer (19). There is a good correlation of passive transcellular absorption of compounds through TC7 and the parental Caco-2 cell monolayer comparable to the extent of permeability in humans. The TC-7 model therefore offers an alternative to Caco-2 for intestinal permeability assessment of test compounds. In addition, TC-7 has an advantage over Caco-2 by expressing high levels of CYP3A4 enzymes well represented in the intestine. However, TC-7 unlike Caco- 2 cell lacks transport proteins and therefore its application is skewed towards metabolism of drug employing CYP3A4.

2/4/A1 originates from fetal rat intestine and is considered to mimic intestinal passive paracellular permeability in humans better than Caco-2 monolayer $(52,53)$. This immortalized cell is reported to differentiate monolayers with tight junctions, brush-border membrane enzymes and transporter proteins. Unlike, Caco-2, tight junctions expressed in 2/4/A1 are loose and better for studies of compounds absorbed in the human intestine via the paracellular route. The model has been proven to 
be excellent for prediction of poorly absorbed compounds such as mannitol and creatinine better than Caco-2 but comparable to that of human jejunum (52,53). Table 3 summarises the comparison of Caco-2 with other cell-based models for intestinal permeability analysis.

\section{Generalized Caco-2 cells study protocol Caco-2 Cell Culture}

Caco-2 cells are seeded in standard cell culture medium (consisting of Dulbecco's modified Eagle's medium supplemented with fetal bovine serum, nonessential amino acids, penicillin, and streptomycin) onto 24 transwell membrane inserts at specified cells concentration under a temperature of $37^{\circ} \mathrm{C}$ in an atmosphere of $5 \% \mathrm{CO}_{2}$ and $90 \%$ relative humidity. The cell monolayers are employed for transport studies 15 - 21 days after seeding between different passages (54).

\section{Cell viability}

Caco-2 cells are seeded onto Petri dishes (area 9.2 $\mathrm{cm}^{2}$ ) at a density of $2 \times 10^{5}$ cells $/ \mathrm{cm}^{2}$ and cultured for $24 \mathrm{~h}$. Investigated compound or transport medium (control) is added and incubated for $2 \mathrm{~h}$. The cells are then released from the dishes and incubated with
0.4\% Trypan blue for $5 \mathrm{~min}$ and counted under a microscope (55).

\section{Assessment of monolayer integrity}

The integrity of Caco-2 cell monolayer can be determined by monitoring the paracellular permeability of ion and hydrophilic compounds using TransEpithelial Electrical Resistance (TEER) and ${ }^{14} \mathrm{C}$-mannitol respectively after the experiment. Mannitol is water soluble, cell membrane impermeable and non-ionisable small molecule with molecular weight of $182 \mathrm{~g} / \mathrm{mol}$ and radius $4.1 \mathrm{~nm}$. The low permeability of mannitol $(<0.5 \%$ per hour $)$ is used as a criterium to determine integrity of the Caco-2 monolayer. It is imperative to assess the integrity of the monolayer with ${ }^{14} \mathrm{C}$-mannitol after the actual permeability experiment or during the permeability experiment in the absence and presence of test compounds and control. TEER provides faster and reliable alternative method of assessing Caco-2 cell monolayer intensity. The TEER of monolayer is measured post equilibrating the monolayer in a transport buffer with ERS Voltmeter. The integrity of the monolayer is confirmed by measuring the TEER after each permeability experiment (56).

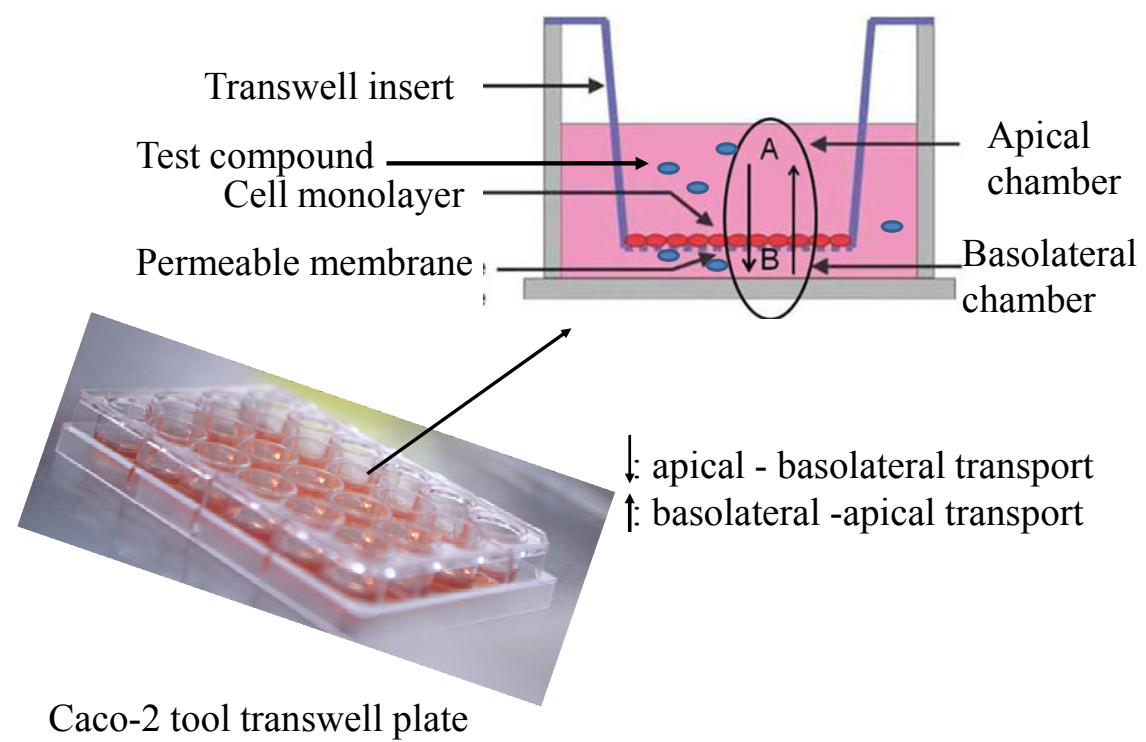

Figure 3. Caco-2 cell in transwell plate (57) 


\section{Bidirectional transport assay}

Prior to all experiments, the inserts (figure 3) are washed twice and equilibrate with pre-warmed transport medium at $37^{\circ} \mathrm{C}$ for $30 \mathrm{~min}$. The transport experiment is initiated by addition of diluted probe substrate (positive control) in the presence or absence of the test substrate to either the apical (for apical to basolateral transport; AP - BL) or basolateral (for basolateral to apical transport; BL AP) side of the monolayer. The monolayers are then placed in an incubator at $37^{\circ} \mathrm{C}$. The samples are withdrawn from either compartment at different time intervals (e.g. 30, 60, 90 and $120 \mathrm{~min}$ ) for H PLC analysis or liquid scintillation spectrometry $(58,59,60)$.

\section{Data analysis of transport}

The apparent permeability coefficient, Papp $(\mathrm{cm} / \mathrm{s})$ is determined as:

$$
\left.p_{a p p=(\delta Q / \delta t}\right) \times\left(1 / A^{\times} \quad C_{o}\right)
$$

Where $\delta \mathrm{Q} / \delta \mathrm{t}$ is the permeability rate, the amount of drug appearing in the receiver as a function of time $(\mathrm{nmol} / \mathrm{s}), C_{o}$ is the initial concentration in the donor chamber $(\mathrm{nmol} / \mathrm{ml})$, and $\mathrm{A}$ is the surface area of the monolayer $\left(\mathrm{cm}^{2}\right)$ as published by Engdal and Nilsen (37).

The direction of probe substrate transport in the monolayer can be determined as passive or active using the $\mathrm{P}_{\text {app }}$ uptake ratio:

$$
\mathrm{P}_{\text {app }} \text { uptake } \quad \text { ratio }=\mathrm{P}_{\mathrm{app}}\left(\frac{\mathrm{AP}-\mathrm{BL}}{\mathrm{BL}-\mathrm{AP}}\right)
$$

The net substrate flux can be calculated as the difference between the B-A and the A-B flux, J:

$$
J N e t=J(B-A)-J(A-B)\left(\mathrm{nmol} \mathrm{cm} \mathrm{cm}^{-2} \mathrm{~h}^{-1}\right)
$$

Where: $\mathrm{J}=\mathrm{P}_{\text {app }} * \mathrm{C}_{\mathrm{o}}\left(\mathrm{nmol} \mathrm{cm} \mathrm{ch}^{-2}\right)$

Percentage inhibition is calculated according to:

$\%$ inhibition $=\left(100-\frac{J \text { Net, inhibition }}{\text { JNet, control }}\right) \times 100$
Evidence of herb-drug interactions in Caco-2 cell model at transporter level

The Caco-2 cell model is capable of expressing intestinal efflux and uptake transporters which regulate permeation of drugs, and herbs from intestinal lumen to systemic circulation. Herbal remedies contain numerous phytochemical compounds with functional groups identical to those found in conventional drugs. The availability of compounds with similar functional groups in both herbal medicines and drugs causes substrate overlap at receptor sites to generate herb-drug interactions when co-administered $(61,62)$. Clinical studies have reported impact of herb-drug interactions on disposition of therapeutics in patients and healthy individuals. For example, the most common implicated herbal medicine, St. John's wort (SJW) is reported to reduce bioavailablity of different drugs including digoxin $(63,64,65)$, amitriptyline (66), oral contraceptives (ethinyl estradiol and norethindrone) (67), or cyclosporine $(68,69,70,71,72,73,74,75$, 76) . The widespread effect of SJW on drugs for management of diverse pathological conditions has been attributed to the induction of P-gp by a bioactive compound hyperforin, modulating the expulsion of these drugs from enterocytes into the intestinal lumen. The Caco-2 cell line is used as a pre-clinical model to predict the possibility of herbdrug interactions ex vivo subsequent to clinical trials.

The prediction of drug-drug and herb-drug interactions involving drug transporters is inferred from pre-clinical evidence from cell lines and animal models. In vitro studies have shown that, green tea, garlic and milk thistle extracts inhibit activity of Pgp $(77,78,79)$ whilst genisten, a bioactive compound in soybean, inhibits activities of both P-gp and MRP2 $(80,81)$. In vitro study conducted in human embryonic kidney (HEK) 293 cells stably expressing OATP-B (HEK/OATP-B cells) employing extracts of bilberry, enchinacea, green tea, banana, grape seed, gingkgo and soybean produced significant inhibition of OATP-B mediated uptake of estrone-3sulfate (82).

In a recent study, $50 \mathrm{ml}$ of "untreated" Red Yeast Rice aqueous extract (RYR) of a concentration $0.5 \mathrm{mg} / \mathrm{ml}$ were added into the apical compartment of Caco-2 tissue culture plates in the presence of verapamil as a P-gp probe substrate. The study showed a 2-fold increase in the net absorption of verapamil from apical membrane to the basolateral compartment, an indicative of a potential inhibitory 
effect of RYR on intestinal P-gp. A further study was conducted in intact animal to confirm the result from caco- 2 cell line. The result showed 30 minutes postadministration of verapamil in pre-treated "untreated" RYR rat models produced a 2-fold plasma concentration of P-gp probe substrate compared to the control which concurred with the outcome of the in vitro study (83).

Ginseng is one of the most recognised traditional Chinese medicines reported to exhibit anticancer effect due to presence of 20(S)-Ginsenoside Rh2 [20(S)-Rh2], a trace element in gingseng $(84,85)$. In 2010, a study conducted by Zhang and others revealed that presence of $20(S)-\mathrm{Rh} 2$ significantly reduced transport of three classical P-gp probe substrates; digoxin, fexofenadine, or etoposide across Caco-2 monolayers in basolateral to apical direction but increased digoxin or etoposide transport in the apical to basolateral direction. The result reveals that $20(S)-\mathrm{Rh} 2$ inhibits efflux activity of P-gp whilst uptake transporters in the apical membrane are induced which could result in potential systemic toxicity of the substrates. Further study was conducted in Sprague-Dawley rats intragastrically treated with $20(S)-\mathrm{Rh} 2$ in the presence of the three P-gp probe substrates as a follow-up investigation of the in vitro result. The outcome of this in vivo study revealed an increase in AUC and $\mathrm{C}_{\max }$ for all the substrates without any impact on their terminal elimination half-life. This suggests that the bioactive compound increase absorption of the substrates by inhibiting P-gp similar to that observed in the in vitro study (86).

Oga and co-workers (2012) investigated the impact of herbal medicines used for treatment of malaria on P-glycoprotein mediated efflux in Caco2 cell monolayer in the presence and absence of digoxin (87). Their investigation showed a significant inhibition of digoxin from basolateral to apical membrane of Caco-2 cell monolayer when extracts from Vernonia amydalina, Carica papaya and Tapinanthus sessilifolius were independently applied. Thus, these herbal medicines may increase bioavailability of antimalaria drugs once concomitantly administered. The increase systemic circulation of antimalaria drugs could become toxic to the liver (88).

Thus concomitant administration of herbs and drugs which are substrates for P-gp may either cause therapeutic failure and pre-systemic toxicity due to induction of the transporter or systemic toxicity as a result of inhibition of the efflux transporter. The role of in vitro cell culture systems in preclinical studies involving HDI therefore cannot be overemphasized. The Caco- 2 cell is therefore often employed to assess functions of intestinal membrane transporters especially P-gp during HDI studies since most herbs are consumed orally.

\section{Common Pitfalls in Caco-2 Assays Variations in passive and carrier-mediated transports}

Pharmaceutically relevant uptake transport proteins (e.g. peptide transporters, organic cation transporter and OAT) are under-expressed in Caco-2 monolayer compared to the level of expression in vivo $(89,90,91)$. Studies have demonstrated poor permeability of $\beta$-lactam antibiotics (e.g. cephalexin and amoxicillin) and ACE inhibitors across Caco-2 cell monolayer although these dipeptide transporter substrates are completely absorbed in vivo (92) . Also, it has been shown that there is significant variation of mRNA expression levels of efflux transporters in Caco-2 cell monolayer compared to small and large intestines in humans. For example, the transcription of BCRP (ABCG2) is about a 100fold lower in Caco-2 cells compared with jejunum $(99,93,94)$. The differences in transporter proteins expression in Caco-2 cell monolayer generate false negative findings that may not correlate with in vivo studies.

The source of Caco-2 cell and inter-laboratory variations in protocol design contribute to discrepancies in paracellular permeability of compounds in the monolayer. Studies have shown that, the source of Caco-2 cell could provide a 100fold variation in the permeability of mannitol (95) and 20-fold differences in TEER due to different culture conditions and composition of cell subpopulation (30). Inter-laboratory differences in TEER values influence the estimation of passive transport of compounds since the TEER value is used to determine the expression of tight junction. For instance, the low molecular weight hydrophilic compounds (e.g. metformin, ranitidine, atenolol, furosemide or hydrochlorothiazide) are wellabsorbed in humans. However, poor permeability of these compounds has been observed in Caco-2 cell monolayer similar or even less than that of mannitol. This drug transport abnormality poses a problem to properly predicting the in vivo-in vitro correlation of 
data from different laboratories due to variable outcomes.

\section{Low expression of CYP3A4}

Intestinal CYP3A4 plays a vital role in first pass metabolism of drugs and herbs. An ideal cell-based model for intestinal permeability studies should mimic the human gastrointestinal enterocytes by expressing metabolic enzymes together with the lipid bilayer interspersed with transporters and tight junctions to give a fair representation of the interplay between CYP3A4 and P-gp. The Caco-2 cell monolayer fails to simulate in vivo intestinal environment due to low expression of CYP3A4 which is considered as the main drug-metabolizing enzyme in the human epithelial cells.

\section{Loss of compounds - Membrane retention and non- specific binding}

Membrane retention also called cacophilicity refers to the tendency of a drug to reversibly bind to Caco2 cells causing incomplete recovery and inaccurate data interpretation. Incomplete recovery is especially common with lipophilic drug candidates. Several factors including: the amount of drugs that appeared in the receiver compartment, the initial concentration in the donor compartment, and the surface area of the physical barrier (e.g, lipid bilayers and cell monolayer) affect permeability of drugs. The drug can also non-specifically bind to plastic devices (transwell plates), reducing the concentration of drug in the donor and receiver compartments during incubation period and therefore leading to underestimation of permeability estimates, and false negatives. Non-specific binding can also occur during transfer of cultured sample together with the drug into another container. Few approaches may be helpful to reduce this problem. The final donor concentration may be preferred to initial donor concentration at the termination of incubation since the non-specific binding occurs relatively faster. The second approach involves addition of bovine serum albumin to the receiver compartment to minimize non-specific binding of lipophilic drugs, thus, improve the assay recovery and overall predictability $(96,97,98)$. Application of organic solvent such as acetonitrile into containers ready to receive transferred cultures has also been helpful to reduce loss of compounds due to non-specific binding to plastic devices.

\section{Lack of adequate solubility}

The permeability assessment of test compounds in Caco-2 is underestimated due to poor aqueous solubility. Organic cosolvent such as DMSO and propylene glycol are added to the donor compartment to avert this problem. However, the Caco-2 cell monolayer can tolerate these organic solvent at a concentration $\sim 1-2 \% \mathrm{v} / \mathrm{v}$. Beyond this concentration, the cell tight junction is compromised and renders the monolayer impracticable. However, some solvents such as Tween 80 , cremophor and pluronic which are known inhibitors of efflux transporters must be avoided $(99,100,101)$. Intestinal $\mathrm{pH}$ variations from the upper small intestine to the distal large intestine determine the nature of compounds absorbed at a specific region. For example, weak acidic drugs remain unchanged in the upper small intestine due to high $\mathrm{pH}$, therefore passive transcellular transport emerge as the dominant route of absorption into the circulation. Caco-2 studies are incapable of simulating the changes of intestinal $\mathrm{pH}$ system since it is performed at constant $\mathrm{pH}$ conditions (apical $\mathrm{pH}$ of 6.5 and basolateral $\mathrm{pH}$ of 7.4). Any $\mathrm{pH}$ modification in design of Caco-2 cell protocol may affect its cytoarchitecture and underestimate the permeability characteristics.

\section{Other experimental variability}

Different laboratories operate under diverse experimental conditions such as culturing, passage number and culture duration which account for variations in permeability values. The interlaboratory variations affect the expression levels of efflux transporters which depend on the age of the cell cultures (19). The Caco-2 subclones expressing high levels of efflux transporters are currently preferred to establish structure-transport relationship for efflux transporters. Few challenges have been encountered during analysis of samples using various instruments such as HPLC or LC-MS. These instruments are expected to produce accurate results due to their sensitivity. However, presence of high salt component in transport buffer (e.g. HBSS) interferes with ionization and hence complicates development of steady LC-MS methods.

\section{Current and future approaches}

Quality high throughput devices are employed by dedicated laboratories for screening large quantities of new drugs. Most of these new devices are 
developed through integration of advance knowledge in molecular biology and combinatorial computer into conventional in vitro models. A few of these recent developments in Caco-2 cell permeability assay which may eventually replace the conventional techniques in the coming years are discussed below.

\section{Automation and Robotic systems}

Cell culturing requires several hours of repetitive, painstaking manual procedures in order to maintain absolute sterility. Additionally, maintenance of favourable environmental conditions via the cell culture cycle; growth, harvesting, re-seeding and analysis are important. Cell growth therefore demands careful regulation of several factors in an attempt to achieve viable and consistent Caco- 2 cell lines. In conditions where large quantities of permeability assay of compounds are analysed, there is a high propensity of cell contamination. This difficulty has propelled pharmaceutical companies to embrace the use of automated Caco-2 cell culture system. An automated Caco-2 system can be employed to study 200-500 compounds within a month without any increase in the cost of operation.

Robotic systems are capable of performing both the cell culture and high throughput screening assay of drug candidates. Most robotic systems perform multi-purpose tasks such as plate coating, seeding and cell feeding. The robotic system uses key components (articulating arms and plate carousel) to automate the cell culture procedure. The articulating arms hold plates at different angles allowing the user to dispense media on the wall of the plate, reducing possible cell or membrane damage (19).

\section{Ready-to-use Caco-2 models}

Modified Caco-2 cell models which are ready for permeability analysis within culturing time of 3-7 days have been produced by dedicated laboratories to curtail the long period associated with parental culture procedure. Some of these modified models are currently used for permeability analysis of new drugs. Typical example of modified models, Biocoat $^{\mathrm{TM}}$ HTS Caco-2 Assay System promotes rapid differentiation of Caco-2 cells. The system is accompanied by a specialized media formulation that facilitates differentiation of the cell monolayer within three days. Major pharmaceutical industries globally now depend on Biocoat ${ }^{\mathrm{TM}}$ HTS Caco-2 Assay System for oral permeability evaluation of new drugs. CacoReady ${ }^{\mathrm{TM}}$ is another innovative cellbased and ready to use kit for intestinal permeability analysis. The kits composed of 24 and 96 insertintegrated permeable supports seeded with differentiated and polarized Caco-2 barriers on polycarbonated microporous filters. A comparative study to assess permeability efficient of parental Caco-2 and Biocoat ${ }^{\mathrm{TM}}$ HTS Caco-2 assay system using parabens; a preservative commonly used in food, cosmetics and pharmaceutical industries showed better absorption in ready-to-use Caco-2 as illustrated by figure 4 (102). Ready-to-use Caco-2 cell has several advantages over parental Caco-2: high flexibility, time saving and cost effective, easy to set up, high reproducibility and adaptable to automated procedures and high throughput screening. However, low expression of enzymes and transporters has been reported due to inadequate duration for culturing $(103,104)$.

\section{Transfected Caco-2 cell line}

The advances made in modern molecular biology and genetic information are exploited fully to enhance functional expression of transporters and CYP using Caco-2 cell lines. The expression level of specific transporters in Caco-2 may be manipulated either transiently or stably according to the preference of the researcher (105). Construction of transfected Caco- 2 cell line is relevant to transporters such as PEPT1 that cannot be expressed under normal culture conditions. In a study conducted to characterized the cellular uptake mechanism of amino acid ester prodrugs of nucleoside antiviral drugs in the transiently transfected Caco-2 cells overexpressing a human intestinal peptide transporter, hPEPT1 (Caco-2/hPEPT1 cells), the transfected cell line produced five times higher uptake than parental Caco-2 (106) . However, induction of efflux transporters is often easier and well-expressed in parental Caco-2 compared to transfected cells. Hence, transfection of efflux transporters in Caco-2 cell is not recommended.

The Caco-2 cell line can also be transfected with extra-chromosomal CYP vectors. Caco-2 cells transfected with CYP3A4 have been successfully employed to investigate the interplay of CYP enzymes and efflux pumps at the intestinal epithelium (107). Nevertheless, transfected Caco-2 harbouring extra-chromosomal CYP have been withdrawn from the market due to its lack of longterm stability. 

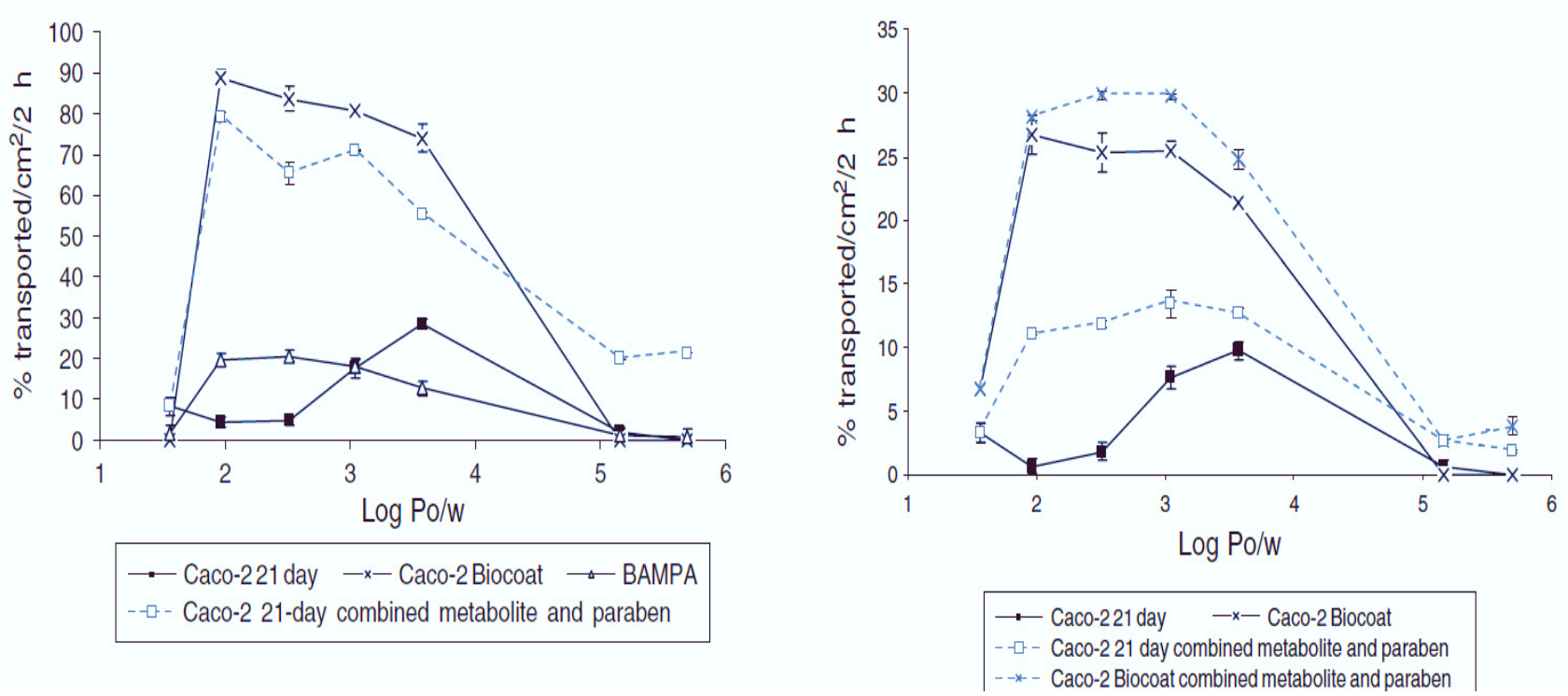

Figure 4. comparative permeability assessment between parental and ready-to-use Caco-2 models using paraben adopted from Lakeram et al. (110).

Molecular biology technology has been used to modulate the expression of nuclear receptors that are principal regulators of gene expression for CYP enzymes. Caco-2 cells transfected with human PXR and HNF4 genes showed an increased expression of both nuclear receptors under CYP3A4 promoter control (108).

The functional expressions of efflux and uptake transporters in Caco-2 monolayer depend on the passage number and other inter-laboratory conditions. These variations have resulted in inconsistent expression of drug transporter during permeability assays. In recent years, dedicated laboratories have introduced engineered cell lines which explicitly over-express a specific efflux or uptake transporter for better examination of drugtransporter interactions. The newly constructed cell line selectively express transporter of interest and enhance interaction study with a specific transporter in isolation. Bidirectional investigations conducted in engineered Caco-2 cell line are devoid of interference from other transporter since only a specific transporter is teased out. The functional expression of transporters in transfected cell line appears more stable than parental Caco-2 cell.

\section{Knockdown Caco-2 cell line}

Selectively knocking down specific endogenous genes is an alternative to construct modified Caco-2 cell line with a decreased transporter expression.
Several attempts have been made to produce Caco-2 cell lines deficient in P-glycoprotein. Hilgendorf and co-workers were first to use antisense technique to reduce transcription and activity of P-gp. Currently, modern siRNA technology is employed to reduce Pgp activity in Caco-2 cells. Although siRNA technology drastically reduced P-gp expression, conflicting results have been reported (109). Celius and others (110) reported that complete abolishment of P-gp is unachievable whilst Watanabe and coworkers (111) experiment produced complete loss of both MDR1 mRNA and P-gp expression. The application of siRNA technology in Caco-2 cell line must be done with caution to prevent misrepresentation of data.

\section{CONCLUSION}

The Caco-2 model is widely used as a tool for permeability and/or absorption screening of test compounds during decision-making process in the early stages of drug discovery. The use of Caco-2 cell line for herb-drug interactions screening is increasingly gaining grounds in the academia and dedicated laboratories due to its popularity and acceptability. The recommendation of Caco-2 cell line by the FDA as an integral component of the Biopharmaceutics Classification System (BCS) has given this model an advantage over the other cellbased models (112). Consequently, the routine 
application of Caco-2 cell for screening of biopharmaceutical parameters of test compounds such as herbal medicines in dedicated laboratories requires reliable protocol to generate reproducible results. The pitfalls enumerated in this review may undermine the credibility of results generated from different laboratories due to protocol variations. However, the incorporation of current and future technologies discussed in this paper into Caco- 2 cell line study protocol during herb-drug interactions investigations may reduce some of these caveats. The dedicated laboratories engaged in screening of herbs and NCE must therefore embrace the paradigm shift of the emerging technologies associated with the application of Caco-2. This will improve the reproducibility of results from different laboratories and help decision making bodies to give right recommendations for clinical trials based on the preclinical information

\section{ACKNOWLEDGEMENT}

The authors acknowledge support of the NIHFogarty International Center training grant-Brown AIDS International Training and Research Program (Grant\# D43TW000237) for providing funds for this study.

\section{REFERENCES}

1. Pharmaceutical Profiling in Drug Discovery for Lead Selection. Borchardt, R.T., Kerns, E.H., Lipinski, C.A., Thakker, D.R. \& Wang, B. W. Washington DC, AAPS Press, 93-126. 2004.

2. Abrahamsson, B., Lennernas, H.,. Application of the biopharmaceutic classification system now and in the future. Drug Bioavailability, Estimation of Solubility, Permeability, Absorption, and Bioavailability. Waterbeemd, H.v.d., Lennernas, H. \& Artursson, P., wiley-vch. 18: 495-531, 2005.

3. Martinez MN, Amidon GL. A mechanistic approach to understanding the factors affecting drug absorption: a review of fundamentals. J Clin Pharmacol, 2002; 42: 620-643.

4. WaterBeemd V, Jones C. Predicting oral absorption and bioavailability. Prog Med Chem, 2003; 41: 159.

5. Penzotti J, Landrum GA, Putta S. Building predictive ADMET models for early decisions in drug discovery. Curr Opin Drug Discovery Dev, 2004; 7: $49-61$.

6. Miret S, Abrahamse L, de Groene EM. Comparison of in vitro models for the prediction of compound absorption across the human intestinal mucosa. J

Biomol Screen, 2004; 9: 598-606.

7. Balimane PV, Chong S, Morrison RA. Current methodologies used for evaluation of intestinal permeability and absorption. J Pharmacol Toxicol Methods. 2000; 44: 301-312.

8. Hidalgo IJ, Raub TJ, Borchardt RT. Characterization of the human colon carcinoma cell line (Caco-2) as a model system for intestinal epithelial permeability. Gastroenterology, 1989; 96: 736-49.

9. Bohets H, Annaert P, Mannens G, van Beijsterveldt L, Anciaux K, Verboven P, Meuldermans W, Lavrijsen K. Strategies for absorption screening in drug discovery and development. Curr Top Med Chem, 2001; 1: 367-383.

10. Artursson P, Karlsson J. Correlation between oral drug absorption in humans and apparent drug permeability coefficients in human intestinal epithelial (Caco-2) cells. Biochem Biophys Res Commun, 1991; 175: 880-5.

11. Awodele O, Olayemi SO, Adeyemo TA, Sanya TA, Dolapo DC. Use of complementary medicine amongst patients on antiretroviral drugs in an HIV treatment centre in Lagos, Nigeria. Curr Drug Safety, 2012; 7(2): 120-5.

12. Moltó J, Miranda C, Malo S, Valle M, Andreu A, Bonafont $\mathrm{X}$, Clotet B. Use of herbal remedies among HIV-infected patients: patterns and correlates. Medicina Clinica (Barc). 2012; 138(3): 93-8.

13. Klepser TB, Doucette WR, Horton MR. Assessment of patients' perceptions and beliefs regarding herbal therapies. Pharmacother, 2000; 20: 83-87.

14. Ungell AL, Karlsson J. Cell culture in drug discovery: an industrial perspective. In: van de Waterbeemd H, Lennernäs H, Artursson P, editors. Drug bioavailability. Weinheim: Wiley-Vch., 90131. 2004.

15. Gibaldi M, Boyes RN, Feldman S. The influence of first pass effect on availability of drugs. J Pharm Sci, 1971; 60: 1338-1340.

16. Rowland $\mathrm{M}$. The influence of route of administration on drug availability. J Pharm Sci, 1972; 101: 70-74.

17. Magee DF, Dalley AF. Digestion and The Structure and Function of The Gut (Karger Continuing Education Series, vol. 8). Karger, Basel. 1986.

18. Pang KS. Modeling of intestinal drug absorption: roles of transporters and metabolic enzymes. Drug Metab Dispos, 2003; 31(12): 1507-1519.

19. Balimane PV, Chong S. Cell culture-based models for intestinal permeability: a critique. Drug Discovery Today, 2005; 10: 335-343.

20. Lee K, Thakker DR. Saturable transport of H2antagonists ranitidine and famotidine across Caco-2 cell monolayers. J Pharm Sci, 1999; 88: 680-7. 
21. Thomas VH, Bhattachar S, Hitchingham L, Zocharski P, Naath M, Surendran N, Stoner CL, ElKattan A. The road map to oral bioavailability: an industrial perspective. Expert Opin Drug Met Toxicol, 2006; 2 (4): 591-608.

22. Varma MV, Ambler CM, Ullah M, Rotter CJ, Sun H, Litchfield J, Fenner KS, El-Kattan AF. Targeting intestinal transporters for optimizing oral drug absorption. Curr Drug Met, 2010; 11(9): 730-742.

23. Hurst S, Loi CM, Brodfuehrer J, El-Kattan A. Impact of physiological, physicochemical and biopharmaceutical factors in absorption and metabolism mechanisms on the drug oral bioavailability of rats and humans. Expert Opin Drug Met Toxicol, 2007; 3(4): 469-489.

24. Ho RH, Kim RB. Transporters and drug therapy: implications for drug disposition and disease. Clin Pharmacol Ther, 2005; 78: 260-77.

25. Oostendorp RL, Beijnen JH, Schellens JH. The biological and clinical role of drug transporters at the intestinal barrier. Cancer Treatment Rev, 2009; 35: 137-47.

26. Shugarts S, Benet LZ. The role of transporters in the pharmacokinetics of orally administered drugs. Pharm Res, 2009; 26: 2039-54.

27. Chan LM, Lowes S, Hirst BH. The ABCs of drug transport in intestine and liver: Efflux proteins limiting drug absorption and bioavailability. Eur $\mathrm{J}$ Pharm Sci, 2004; 21:25-51.

28. Yu XQ, Xue CC, Wang G, Zhou SF. Multidrug resistance associated proteins as determining factors of pharmacokinetics and pharmacodynamics of drugs. Curr Drug Metab, 2007; 8: 787-802.

29. Taipalensuu J, Tornblom H, Lindberg G, Einarsson C, Sjoqvist F, Melhus H, Garberg P, Sjostrom B, Lundgren B, Artursson P. Correlation of gene expression of ten drug efflux proteins of the ATPbinding cassette transporter family in normal human jejunum and in human intestinal epithelial Caco-2 cell monolayers. J Pharmacol Exp Ther, 2001; 299: 164-170.

30. Jonker JW, Smit JW, Brinkhuis RF, Maliepaaed M, Beijnen JH, Schellens JHM, Schinkel AH. Role of breast cancer resistance protein in the bioavailability and fetal penetration of topotecan. J Natl Cancer Institute, 2000; 92: 1651-1656.

31. Troutman MD, Luo G, Gan LS, Thakker DR. The role of P-glycoprotein in drug disposition: significance to drug development, in Drug-Drug Interactions (Rodrigues $\mathrm{AD}$ ed) Marcel Dekker, New York, 295-358, 2001.

32. Adachi Y, Suzuki H, Schinkel AH, Sugiyama Y. Role of Breast cancer resistance protein (Bcrp1/Abcg2) in the extrusion of glucuronide and sulfate conjugates from enterocytes to intestinal lumen. Mol Pharmacol, 2005; 67: 923-928.
33. Russel FG, Masereeuw MR, van Aubel RAMH. Molecular aspects of renal anionic drug transport. Ann Rev Physiol, 2002; 64: 563-594.

34. Takikawa H. Hepatobiliary transport of bile acids and organic anions. J Hepato-Biliary-Pancreatic Surgery, 2002; 9: 443-447.

35. Lee VH, Sporty JL, Fandy TE. Pharmacogenomics of drug transporters: the next drug delivery challenge. Adv Drug Deliv Rev, 2001b; 50: S33S40.

36. Kullak-Ublick GA, Ismair MG, Stieger B, Landmann L, Huber R, Pizzagalli F, Fattinger K, Meier PJ, Hagenbuch B. Organic anion-transporting polypeptide B (OATP-B) and its functional comparison with three other OATPs of human liver. Gastroenterology, 2001; 120: 525-533.

37. Engdal S, Nilsen OG. Inhibition of P-glycoprotein in Caco-2 cells: effects of herbal remedies frequently used by cancer patients. Xenobiotica, 2008; 38(6), 559-73.

38. Artursson P. Cell cultures as models for drug absorption across the intestinal mucosa. Crit. Rev. Ther Drug Carr Systems, 1991a; 8: 305 - 330.

39. Artursson P, Karlsson J. Correlation between oral drug absorption in humans and apparent drug permeability coeffi cients in human intestinal epithelia (Caco-2) cells. Biochem Biophys Res Comm, 1991b; 175: $880-890$.

40. Rubas W, Cromwell M, Shahrokh Z. Flux measurements across Caco-2 monolayers may predict transport in human large intestinal tissue. $\mathrm{J}$ Pharm Sci, 1996; 85: 165 - 169.

41. Fogh J, Trempe G. Human Tumor Cells In Vitro (J. Fogh, ed.), Plenum, 115-141, 1975

42. Vachon PH, Beaulieu J-F. Transient Mosaic Patterns of Morphological and Functional Differentiation in the Caco-2 Cell Line. Gastroenterology, 1992; 103: 414-23.

43. Hunter J, Hirst BH. Intestinal secretion of drugs. The role of P-glycoprotein and related drug efflux systems in limiting oral drug absorption. Adv Drug Deliv Rev, 1997; 25:129-157.

44. Prueksaritanont T, Gorham LM, Hochman JH, Tran LO, Vyas KP. Comparative studies of drugmetabolizing enzymes in dog, monkey, and human small intestines, and in Caco-2 cells. Drug Metab Dispos, 1996; 24: 634-642.

45. Balcarova-Ständer J, Pfeiffer SE, Fuller SD, Simons K. Development of cell surface polarity in the epithelial Madin-Darby canine kidney (MDCK) cell line. The EMBO Journal, 1984; 3(11): 2687-94.

46. Braun A, Hammerle S, Suda K, Rothn-Rutishauer B, Guthert M, Kramer SD, Wunderli-Allenspach H. Cell cultures as tools in biopharmacy. Eur J Pharm Sci, 2000; 11: S51-S60. 
47. Li H, Chung SJ, Shim CK. Characterization of the transport of uracil across Caco-2 and LLC-PK1 cell monolayers. Pharm Res, 2002; 19: 1495-1501.

48. Adachi Y, Suzuki H, Sugiyama Y. Quantitative evaluation of the function of small intestinal P-gp: comparative studies between in situ and in vitro. Pharm Res, 2003; 20:1163-1169.

49. Thwaites D, Hirst BH, Simmons NL. Passive transepithelial absorption of thyrotropin-releasing hormone (TRH) via a paracellular route in cultured intestinal and renal epithelial cell line. Pharm Res, 1993; 10: 674-681.

50. Lesuf eur T, Kornowski A, Luccioni C, Muleris M, Barbat A, Beaumatin J, Dussaulx E, Dutrillaux B, Zweibaum A. Adaptation to 5-fuorouracil of the heterogeneous colon tumor cell line HT-29 results in the selection of cells commited to differentiation. Int J Cancer, 1991a; 49: 721-730.

51. Lesuf eur T, Barbat A, Luccioni C, Beaumatin J, Clair M, Kornowski A, Dussaulx E, Dutrillaux B, Zweibaum A. Dihydrofolate reductase gene ampli ${ }^{2}$ cation-associated shift of differentiation in methotrexate-adapted HT-29 cells. J Cell Biol, 1991b; 115: 1409-1418.

52. Tavelin S, Taipalensuu J, Hallbook F, Vellonen KS, Moore V, Artursson P. An improved cell culture model based on 2/4/A1 cell monolayers for studies of intestinal drug transport: Characterization of transport routes. Pharm Res, 2003a; 20: 373-381.

53. Tavelin S, Taipalensuu J, Soderberg L, Morrison R, Chong S, Artursson P. Prediction of the oral absorption of low-permeability drugs using small intestine-like 2/4/A1 cell monolayers. Pharm Res, 2003b; 20:397-405.

54. Elsby R, Surry DD, Smith VN, Gray AJ. Validation and application of Caco-2 assays for the in vitro evaluation of development candidate drugs as substrates or inhibitors of P-glycoprotein to support regulatory submissions. Xenobiotica, 2008; 38: $1140-1164$.

55. Lu Y, Heydel JM, Li X, Bratton S, Lindblom T, Radominska-Pandya A. Lithocholic acid decreases expression of UGT2B7 in Caco-2 cells: a potential role for a negative farnesoid $\mathrm{X}$ receptor response element. Drug Metab Dispos, 2005; 33: 937-46.

56. Hidalgo I, Li J. Carrier-mediated transport and efflux mechanisms in Caco-2 cells. Adv Drug Deliv Rev, 1996; 22: 53-66.

57. Shah P, Jogani V, Bagchi T, Misra A. Role of Caco2 Monolayers in Prediction of Intestinal Drug Absorption. Biotechnol Prog, 2006; 22: 186-98.

58. Smetanova L, Stetinova V, Kholova D. Caco-2 cells and Biopharmaceutics Classification System (BCS) for prediction of transepithelial transport of xenobiotics (model drug: caffeine). Neuro Endocrinol Letters, 2009; 30 (Suppl. 1):101-5.
59. Stetinova V, Smetanova L, Kholova D. Transepithelial transport of ambroxol hydrochloride across human intestinal Caco-2 cell monolayers. Gen Physiol Biophys, 2009;28: 309-15.

60. Walle UK, Walle T. Taxol transport by human intestinal epithelial Caco-2 cells. Drug Metab Dispos, 1998; 26: 343-6.

61. Marchetti S, Mazzanti R, Beijnen JH. Concise review: clinical relevance of drug-drug and herbdrug interactions mediated by the $\mathrm{ABC}$ transporter ABCB1 (MDR1, P-glycoprotein). Oncologist, 2007; 12: 927-941.

62. Fasinu PS, Bouic PJ, Rosenkranz B. An overview of the evidence and mechanisms of herb- drug interactions. Front Pharmacol, 2012; 3: 69.

63. Ioannides C. Pharmacokinetic interactions between herbal remedies and medicinal drugs. Xenobiotica, 2002; 32: 451- 478 .

64. Johne A, Brockmoller J, Bauer S, Maurer A, Langheinrich M, Roots I. Pharmacokinetic interaction of digoxin with an herbal extract from $\mathrm{St}$ John's wort (Hypericum perforatum). Clin Pharmacol Ther, 1999; 66: 338-345.

65. Mueller SC, Uehleke B, Woehling H. Effect of St John's wort dose and preparations on the pharmacokinetics of digoxin. Clin Pharmacol Ther, 2004; 75: 546-557.

66. Johne A, Schmider J, Brockmoller J. Decreased plasma levels of amitriptyline and its metabolites on comedication with an extract from St. John's wort (Hypericum perforatum). J Clin Psychopharmacol, 2002; 22: 46-54.

67. Hall SD, Wang Z, Huang SM. The interaction between St John's wort and an oral contraceptive. J Clin Pharmacol Ther, 2003; 74: 525-535.

68. Ahmed SM, Banner NR, Dubrey SW. Low cyclosporin-A level due to St. John's wort in heart transplant patients. J Heart Lung Transplant, 2001; 20: 795.

69. Alscher DM, Klotz U. Drug interaction of herbal tea containing St. John's wort with cyclosporine. Transplant International, 2003; 16: 543-544

70. Barone GW, Gurley BJ, Ketel BL, Lightfoot ML, Abul-Ezz SR. Drug interaction between St. John's wort and cyclosporine. Ann Pharmacother, 2000; 34:1013-1016.

71. Breidenbach T, Hoffmann MW, Becker T, Schlitt H, Klempnauer J. Drug interaction of St John's wort with cyclosporin. Lancet, 2000; 355: 1912.

72. Breidenbach T, Kliem V, Burg M, Radermacher J, Hoffmann MW, Klempnauer J. Profound drop of cyclosporin A whole blood trough levels caused by St. John's wort (Hypericum perforatum). Transplantation, 2000; 69: 2229-2230.

73. Karliova M, Treichel U, Malago M, Frilling A, Gerken G, Broelsch CE. Interaction of Hypericum perforatum (St. John's wort) with cyclosporin A 
metabolism in a patient after liver transplantation. J Hepatol, 2000; 33: 853-855.

74. Mai I, Kruger H, Budde K. Hazardous pharmacokinetic interaction of Saint John's wort (Hypericum perforatum) with the immunosuppressant cyclosporin. Int $\mathrm{J}$ Clin Pharmacolo Ther, 2000; 38: 500-502.

75. Moschella C, Jaber BL. Interaction between cyclosporine and Hypericum perforatum (St. John's wort) after organ transplantation. Am J Kidney Dis, 2001; 38: 1105-1107.

76. Ruschitzka F, Meier PJ, Turina M, Luscher TF, Noll G. Acute heart transplant rejection due to Saint John's wort. Lancet, 2000; 355: 548-549.

77. Jodoin J, Demeule M, Beliveau R. Inhibition of the multidrug resistance Pglyco-protein activity by green tea polyphenols. Biochimica et Biophysica Acta, 2002; 1542:149 - 159.

78. Zhang S, Morris ME. Effects of the flavonoids biochanin A, morin, phloretin and silymarin on Pglycoprotein-mediated transport. J Pharmacol Exp Ther, 2003; 304; 1258-1267.

79. Zhou S, Lim LY, Chowbay B. Herbal modulation of P-glycoprotein. Drug Metab Rev, 2004; 36: 57-104.

80. Jager W, Winter O, Halper B, Salamon A, Sartori M, Gajdzik L, Hamilton G, Theyer G, Graf J, Thalhammer T. Modulation of liver canalicular transport processes by the tyrosinekinase inhibitor genistein: implications of genistein metabolism in the rat. Hepatol, 1997; 26: 1467-1476.

81. Ciolino HP, Daschner PJ, Yeh GC. Dietary flavonols quercetin and kaempferol are ligands of the aryl hydrocarbon receptor that affect CYP1A1 transcription differentially. Biochem J, 1999; 340: 715-722.

82. Fuchikami H, Satoh H, Tsujimoto M, Ohdo S, Ohtani H, Sawada Y. Effects of herbal extracts on the function of human organic anion-transporting polypeptide OATP-B. Drug Metab Dispos, 2006; 4 (4): 577-582.

83. Fung WT, Subramaniam G, Lee J, Loh HM, Leung PHH. Assessment of Extracts from Red Yeast Rice for Herb-Drug Interaction by in-vitro and in-vivo assays. Sci reports, 2012; 2 (298): 1-6.

84. Fei XF, Wang BX, Tashiro S, Li TJ, Ma JS, Ikejima $\mathrm{T}$. Apoptotic effects of ginsenoside $\mathrm{Rh} 2$ on human malignant melanoma A375-S2 cells. Acta Pharmacologica Sinica, 2002; 23: 315-322.

85. Kim HS, Lee EH, Ko SR, Choi KJ, Park JH, Im DS. Effects of ginsenosides $\mathrm{Rg} 3$ and $\mathrm{Rh} 2$ on the proliferation of prostate cancer cells. Arch Pharmacal Res, 2004;27: 429-435.

86. Zhang J, Zhou F, Wu X, Gu Y, Ai H, Zheng Y, Li Y, Zhang X, Hao G, Sun J, Peng Y, Wang G. 20(S)ginsenoside $\mathrm{Rh} 2$ noncompetitively inhibits $\mathrm{P}$ glycoprotein in vitro and in vivo: a case for herb- drug interactions. Drug Metab Dispos, 2010; 38(12): 2179-87.

87. Oga EF, Sekine S, Shitara Y, Horie T. Pglycoprotein mediated efflux in Caco-2 cell monolayers: the influence of herbals on digoxin transport. J Ethnopharmacol, 2012; 144(3): 612-7.

88. Mishra SK, Singh P, Rath SK. A study of toxicity and differential gene expression in murine liver following exposure to anti-malarial drugs: amodiaquine and sulphadoxine- pyrimethamine. Malaria J, 2011; 10: 109.

89. Sun D, Lennernas H, Welage LS, Barnett JL, Landowski CP, Foster D, Fleisher D, Lee KD, Amidon GL. Comparison of human duodenum and Caco-2 gene expression profiles for 12,000 gene sequences tags and correlation with permeability of 26 drugs. Pharm Res, 2002; 19: 1400-1416.

90. Behrens I, Kamm W, Dantzig AH, Kissel T. Variation of peptide transporter (PepT1 and HPT1) expression in Caco-2 cells as a function of cell origin. J Pharm. Sci, 2004; 93: 1743-1754.

91. Anderle P, Huang Y, Sadée W. Intestinal membrane transport of drugs and nutrients: genomic membrane transporters using expression microarray. Eur $\mathrm{J}$ Pharm Sci, 2004; 21: 17-24.

92. Chong S, Dando SA, Soucek KM, Morrison RA. In vitro permeability through Caco-2 cells is not quantitatively predictive of in vivo absorption for peptide-like drugs absorbed via the dipeptide transporter system. Pharm Res, 1996; 13: 120-123.

93. Seithel A, Karlsson J, Hilgendorf C, Bjorquist A, Ungell AL. Variability in mRNA expression of $\mathrm{ABC}$ - and SLC-transporters in human intestinal cells: Comparison between human segments and Caco-2 cells. Eur J Pharm Sci, 2006; 28: 291-9.

94. Taipalensuu J, Tornblom H, Lindberg G, Einarsson C, Sjoqvist F, Melhus H, Garberg P, Sjostrom B, Lundgren B, Artursson P. Correlation of gene expression of ten drug efflux proteins of the ATPbinding cassette transporter family in normal human jejunum and in human intestinal epithelial Caco-2 cell monolayers. J Pharmacol ExpTher, 2001;299:164 - 170.

95. Walter E, Kissel T. Heterogeneity in the human intestinal cell line Caco-2 leads to differences in transepithelial transport. Eur J Pharm Sci, 1995; 3: 215-230.

96. Aungst B, Nguyen NH, Bulgarelli JP, Oates-Lenz K. The influence of donor and reservoir additives on Caco-2 permeability and secretory transport of HIV protease inhibitors and other lipophilic compounds. Pharm Res, 2000; 17: 1175-1180.

97. Krishna G, Chen K, Lin C, Nomeir AA. Permeability of lipophilic compounds in drug discovery using in vitro human absorption model, Caco-2. Int J Pharm, 2001;222: 77-89. 
98. Saha P, Kou J. Effect of bovine serum albumin on drug permeability estimation across Caco-2 monolayers. Eur J Pharm Biopharm, 2002; 54: 319324.

99. Bogman K, Erne-Brand F, Alsenz J, Drewe J. The role of surfactants in the reversal of active transport mediated by multidrug resistance proteins. J Pharm Sci, 2003; 92: 1250-1261.

100. Rege B, Yu LX, Hussain AS, Polli JE. Effect of common excipients on Caco-2 transport of low permeability drugs. J Pharm Sci, 2001; 90: 17761786.

101. Rege B, Kao JP, Polli JE. Effect of non-ionic surfactants on membrane transport in Caco-2 cell monolayers. Eur J Pharm Sci, 2002; 16: 237-246.

102. Lakeram M, Lockley DJ, Sanders DJ, Pendlington R, Forbes B. Paraben transport and metabolism in the biomimetic artificial membrane permeability assay (BAMPA) and 3-day and 21-day Caco-2 cell systems. J Biomol Screen, 2007;12(1): 84-91.

103. Yamashita S, Konishi K, Yamazaki Y, Taki Y, Sakane T, Sezaki H. New and better protocols for a short term Caco-2 cell culture system. J Pharm Sci, 2002; 91:669-679.

104. Bravo SA, Nielsen CU, Amstrup J, Frokjaer S, Brodin B. In-depth evaluation of Gly-Sar transport parameters as a function of culture time in the Caco2 cell model. Eur J Pharm Sci, 2004; 21: 77-86.

105. Brouwer KL, Keppler D, Hoffmaster KA, Bow DA, Cheng Y, Lai Y, Palm JE, Stieger B, Evers R. In Vitro Methods to Support Transporter Evaluation in Drug Discovery and Development. Clin Pharmacol Ther, 2013; 94 (1): 95-112.
106. Han HK, Oh DM, Amidon GL. Cellular uptake mechanism of amino acid ester prodrugs in Caco2/hPEPT1 cells overexpressing a human peptide transporter. Pharm. Res, 1998; 15(9): 1382-6.

107. Cummins CL, Jacobsen W, Benet LZ. Unmasking the dynamic interplay between intestinal Pglycoprotein and CYP3A4. J Pharmacol Exp Ther, 2002; 300:1036-45, 2002.

108. Tirona RG, Lee W, Leake BF, Lan LB, Cline CB, Lamba V, Parviz F, Duncan SA. The orphan nuclear receptor HNF4alpha determines PXR- and CARmediated xenobiotic induction of CYP3A4. Nat Med, 2003; 9: $220-4$.

109. Hilgendorf $C$, Spahn-Langguth $H$, Rhedin $M$, Regardh CG, Lowenadler B, Langguth P. Selective downregulation of the MDR1 gene product in Caco2 cells by stable transfection to prove its relevance in secretory drug transport. Mol Pharm, 2005; 2:6473.

110. Celius T, Garberg P, Lundgren B. Stable suppression of MDR1 gene expression and function by RNAi in Caco- 2 cells. Biochem Biophys Res Comm, 2004; 324: 365-71

111. Watanabe $\mathrm{T}$, Onuki $\mathrm{R}$, Yamashita $\mathrm{S}$, Taira $\mathrm{K}$, Sugiyama Y. Construction of a functional transporter analysis system using MDR1 knockdown Caco-2 cells. Pharm Res, 2005; 22: 1287-93.

112. Kim JS, Mitchell S, Kijek P, Tsume Y, Hilfinger J, Amidon GL. The suitability of an in situ perfusion model for permeability determinations: Utility for BCS Class I biowaiver requests. Mol Pharm, 2006; 3: 686-694. 
Table 1. Selected important membrane transporters involved in intestinal drug absorption

\begin{tabular}{|c|c|c|c|c|c|}
\hline Transporter & Location & & $\begin{array}{l}\text { Expression in } \\
\text { Caco- } 2 \text { cell } \\
\text { line }\end{array}$ & Substrates & Inhibitors \\
\hline P-gp/MDR1 $(A B C B 1)$ & $\begin{array}{l}\text { Tissue } \\
\text { Intestine, liver, } \\
\text { kidney, brain, } \\
\text { placenta, adrenal, } \\
\text { testes }\end{array}$ & $\begin{array}{l}\text { Subcellular } \\
\text { Apical }\end{array}$ & + & $\begin{array}{l}\text { Digoxin,fexofenadine, indinavir, } \\
\text { vincristine, colchicine, topotecan, } \\
\text { paclitaxel }\end{array}$ & $\begin{array}{l}\text { Ritonavir,cyclosporine, } \\
\text { verapamil,erythromycin, } \\
\text { ketocoanzole,itraconazole, } \\
\text { quinidine }\end{array}$ \\
\hline $\operatorname{BCRP}(A B C G 2)$ & $\begin{array}{l}\text { Intestine, liver, } \\
\text { breast, placenta }\end{array}$ & Apical & + & $\begin{array}{l}\text { Daunorubicin, doxorubicin, topotecan, } \\
\text { rosuvastatin, sulfasalazine }\end{array}$ & Elacridar (GF120918), gefitinib \\
\hline MRP1(ABCC1) & Ubiquitous & Basolateral & + & Adefovir, indinavir & $?$ \\
\hline MRP2 $(A B C C 2)$ & $\begin{array}{l}\text { Liver, intestine and } \\
\text { kidney }\end{array}$ & Apical & + & Indinavir, cisplatin, & $\begin{array}{l}\text { Cyclosporine, delaviridine, } \\
\text { efavirenz, emtricitabine }\end{array}$ \\
\hline MRP3(ABCC3) & $\begin{array}{l}\text { Liver, intestine, } \\
\text { kidney and bile } \\
\text { ducts }\end{array}$ & Basolateral & + & Etoposide, methotrexate, tenoposide & $\begin{array}{l}\text { Delaviridine, efavirenz, } \\
\text { emtricitabine }\end{array}$ \\
\hline MRP4 (ABCC4) & $\begin{array}{l}\text { Prostate, lung, } \\
\text { muscle, pancreas } \\
\text { and bladder }\end{array}$ & Apical & + & $\begin{array}{l}\text { Adefovir, tenofovir, methotrexate, } \\
\text { topotecan }\end{array}$ & Celecoxib, diclofenac \\
\hline MRP5(ABCC5) & Ubiquitous & Basolateral & + & $?$ & $?$ \\
\hline MRP6(ABCC6) & Liver and kidney & Basolateral & + & Cisplatin, daunorubicin & $?$ \\
\hline PepT1(SLC15A1) & Intestine, kidney & Apical & + & $\begin{array}{l}\text { Ampicillin, amoxicillin, captopril, } \\
\text { valacyclovir }\end{array}$ & Glycyl-proline \\
\hline OATP 2B1(SLCO2B1) & $\begin{array}{l}\text { Intestine, liver, } \\
\text { kidney, brain }\end{array}$ & Apical & $?$ & Pravastatin & Rifampicin, cyclosporine \\
\hline MCT1(SLC16A1) & $\begin{array}{l}\text { Intestine, } \\
\text { erythrocyte }\end{array}$ & Apical & + & $?$ & $?$ \\
\hline
\end{tabular}

Keys: $+=$ presence and ? = unknown 
Table 3. Comparison of Caco-2 with other cell-based models for intestinal permeability studies

\begin{tabular}{|c|c|c|c|c|c|}
\hline Cell lines & Origin & Specific characteristics & Strengths & Weaknesses & References \\
\hline Caco-2 & $\begin{array}{l}\text { Human colon } \\
\text { adenocarcinoma }\end{array}$ & $\begin{array}{l}\text { Most established cell model } \\
\text { Spontaneous differentiation and } \\
\text { expression of some relevant } \\
\text { efflux transporters } \\
\text { Interlaboratory variations in } \\
\text { expression of uptake transporters }\end{array}$ & $\begin{array}{l}\text { Well developed and } \\
\text { characterized } \\
\text { Easy maintenance } \\
\text { Good reproducibility, } \\
\text { robustness and functional } \\
\text { property of human } \\
\text { intestinal cells. } \\
\text { Extensively used, large } \\
\text { database available }\end{array}$ & $\begin{array}{l}\text { Absence of mucous secreting } \\
\text { goblet cells } \\
\text { Not suitable for paracellular } \\
\text { transport } \\
\text { Low expression of metabolizing } \\
\text { enzymes } \\
\text { 21-days culture period }\end{array}$ & $(i, 78)$ \\
\hline HT29-MTX & Human colon & $\begin{array}{l}\text { Contains mucus-producing } \\
\text { goblet cells }\end{array}$ & Expression of mucin & $\begin{array}{l}\text { Not suitable for carrier-mediated } \\
\text { transport } \\
\text { Unstable mucus layer }\end{array}$ & $\left({ }^{i i}\right.$, iii) \\
\hline LLC-PK1 & Pig kidney & $\begin{array}{l}\text { Polarized cells with low intrinsic } \\
\text { transporter expression } \\
\text { Suitable for transfections }\end{array}$ & $\begin{array}{l}\text { Characterization of passive } \\
\text { transport }\end{array}$ & Absence of P-gp & $(65,67)$ \\
\hline
\end{tabular}


Polarized cells with low intrinsic expression of efflux transporters

Suitable for transfections

\section{Ideal for
purposes}

High CYP 3A4 expression

Similar to Caco-2 efflux transporters

\section{Stable expression of CYP3A4}

High taurocholic acid transport absorbed compounds (leakier pores)
Produces tight junction similar to human intestine

Expression of both transporters and
Under-expression of major

High expression of CYP 3A5 and less of CYP 3A4

Good for medium to low throughput screening. $\left({ }^{\mathrm{iv}}, \mathrm{v}\right)$

$$
\text { metabolizing enzymes }
$$

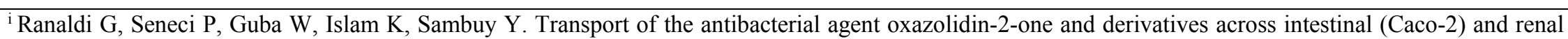
(MDCK) epithelial cell lines. Antimicrob Agents Chemother, 1996; 40: 652-658.

${ }^{i 1}$ Larhed A, Artursson P, BjoErk E. The influence of intestinal mucus components on the diffusion of drugs. Pharm. Res, 1998; 15(1): 66-71.

iii Wikman A, Artursson P, GraÊ sjoÈ J, BjoÈrk E. Diffusion of drugs in native and purified gastrointestinal mucus. J Pharm Sci, 1997 ; 86(6): 660-5.

iv Irvine JD, Lockhart K, Cheong J, Tolan JW, Selick HE, Grove JR. MDCK (Madin-Darby canine kidney) cells: A tool for membrane permeability screening. J Pharm Sci, 1999; 88: 28-33.

v Putnam W, Pan L, Tsutsui K, Takahashi LH, Benet LZ. Comparison of bidirectional cephalexin transport across MDCK and caco-2 cell monolayers: interactions with peptide transporters. Pharm Res, 2002; 19(1): 27-33.

vi Pontier C, Pachot J, Botham R, Lenfant B, Arnaud P. HT29-MTX and Caco-2/TC7 monolayers as predictive models for human intestinal absorption: role of the mucus layer. J Pharm Sci, 2001; 90 (10): 1608-19.
} 